\title{
SEQUELAE OF COVID 19 IN TASTE AND SMELL: A BRIEF LITERATURE REVIEW
}

\section{LITERATURE REVIEW}

CHAVES, leda Bezerra ${ }^{1}$, FECURY, Amanda Alves², OLIVEIRA, Euzébio de ${ }^{3}$, DENDASCK, Carla Viana ${ }^{4}$, DIAS, Claudio Alberto Gellis de Mattos ${ }^{5}$

CHAVES, leda Bezerra. Et al. Sequelae of COVID 19 in taste and smell: a brief literature review. Revista Científica Multidisciplinar Núcleo do Conhecimento. Year. 06, Ed. 11, Vol. 01, pp. 150-166. November 2021. ISSN: 2448-0959, Access Link: https://www.nucleodoconhecimento.com.br/health/sequelae-of-covid-19, DOI: 10.32749/nucleodoconhecimento.com.br/health/sequelae-of-covid-19

\section{SUMMARY}

Viruses are a living being that is not formed by cellular structure. Viruses can be transmitted by direct contact with infected individuals or indirectly from contaminated surfaces. Defined as a new variety of coronaviruses, COVID 19 made the World Health Organization (WHO) declare in early 2020 a crisis in global public health. Considering the high transmissibility of this virus, it was necessary to adopt measures to prevent transmission and infection. Symptoms caused by COVID-19 are usually fever, dry cough, shortness of breath (dyspnea), tiredness (fatigue), sore throat, headache, and diarrhea. Other symptoms, to a lesser extent are anosmia (loss of smell), hyposmia (decreased smell) and ageusia (loss of sense of taste). The

\footnotetext{
${ }^{1}$ Student of Integrated Technical High School in Food, Institute of Basic, Technical and Technological Education of Amapá (IFAP).

${ }^{2}$ Biomedical, PhD in Topical Diseases, Professor and researcher of the Medical Course of Macapá Campus, Federal University of Amapá (UNIFAP).

${ }^{3}$ Biologist, PhD in Topical Diseases, Professor and researcher of the Physical Education Course, Federal University of Pará (UFPA).

${ }^{4}$ Theologian, PhD in Clinical Psychoanalysis. He has been working for 15 years with Scientific Methodology (Research Method) in the Scientific Production Guidance of Master's and Doctoral students. Specialist in Market Research and Research focused on health. PhD student in Communication and Semiotics (PUC SP). ${ }^{5}$ Biologist, PhD in Theory and Behavior Research, Professor and researcher of the Chemistry Degree Course of the Institute of Basic, Technical and Technological Education of Amapá (IFAP) and the Graduate Program in Professional and Technological Education (PROFEPT IFAP).
}

RC: 101279

Available in: https://www.nucleodoconhecimento.com.br/health/sequelae-of-covid-19 
objective of this was to review the last two years on the sequelae of COVID 19 in taste and smell. A brief literature review was conducted in scientific articles on the sequelae of COVID 19 in taste and smell, between 2020 and 2021, in Portuguese, in the Google Scholar search database. Women and young people are the most affected by the sequelae of taste and smell caused by COVID-19. there are no specific and scientifically proven treatments to the various dysfunctions, but the most indicated is the practice of olfactory training. Studies related to dysfunctions are limited, mainly, in Brazil and when they are analyzed as sequelae. The continuity of scientific research is indispensable, because only this process will be able to elucidate the doubts that still exist and generate appropriate treatments for people who developed COVID-19.

Keywords: Virus, COVID 19, Dysosmia, Dysgeusia.

\section{INTRODUCTION}

Viruses are a living being that, unlike the other ones, is not formed by cell. It usually has a nucleic acid (which can be DNA or RNA), covered by a protein "capsule". Some are still covered by "pieces" of cell membrane, which create an "envelope" around it. They are often smaller than a cell and parasitize them, entering them, and using their structures to produce more viruses (they are mandatory intracellular parasites) (Brandão, 2015; They, 2020).

Viruses can be transmitted by direct contact with infected individuals or indirectly from contaminated surfaces. They are transmitted from one individual to another through water droplets in the form of steam released into the breath or during the coughing or sneezing process. Smaller droplets released along with water vapor during these processes are suspended in the air spreading the virus over larger areas and longer. (Brazil, 2021). In contact with one of these means of transmission the viruses invade the mucous cells of the airways and digestórias (Stephens et al., 2009; Silva et al., 2020). 
To be reproduce the viruses bind to the surface of the cell membrane. After this binding it can penetrate the cell or it can "inject" its genetic material (DNA or RNA) into its cytoplasm. Once inside the cells the genetic material of the virus is copied several times, using the chemical reactions it can make. Similarly, other chemical reactions of the cell are used to make the "covers" of protein (capsids). Thus new viruses are mounted inside a cell and, to go out and invade new cells, break the membrane of those who manufactured them (They, 2020; Silva et al., 2020a).

Defined as a new variety of coronaviruses, COVID 19 made the World Health Organization (WHO) declare in early 2020 a crisis in global public health (Souza et al., 2020). These viruses, with a high transmission rate, consist of envelopes of lipids and proteins (piece of membrane of a cell), and protein capsids, with a single rna tape (nucleic acid), and with external crown shape (Silva et al., 2020). They are part of the family of viruses that generate common colds to more severe infections, such as Middle East Respiratory Syndrome (MERS) and Severe Acute Respiratory Syndrome (SARS) (Brazil, 2021; 2021a).

Considering the high transmissibility of this virus, it is necessary to adopt measures to prevent transmission and infection. Among some of these preventive actions, we highlight the non-permanence in closed places and isolation of infected people (Stephens et al., 2009).

Ways considered to be the most efficient and to avoid contamination (prophylaxis) include: hand washing, social distancing, aeration of environments and their exposure to sunlight, cleaning of objects and surfaces, prohibition of agglomerations, and the use of masks (efficient blockers of scattered respiratory droplets, even at reduced distances with direct or indirect contact) (Garcia, 2020). These control measures are proven effective, through scientific analyses and studies, in reducing contamination and viral dissemination (Soares et al., 2021).

Symptoms caused by COVID-19 in general are fever, dry cough, shortness of breath (dyspnea), tiredness (fatigue), sore throat, headache and diarrhea (Silva et al., 
2020). Other symptoms, to a lesser extent are anosmia (loss of smell), hyposmia (decreased smell) and ageusia (loss of sense of taste) (Iser et al., 2020).

Sequelae can be defined as a change in the functioning of cells and/or in the form and functioning of organs causing a permanent defect or not in the individual (Filho, 2011; Vana and Schiozer, 2013).

Among the various sequelae found in individuals who had COVID19 are those of psychological and biological nature, such as changes in the respiratory, cardiovascular systems, possible skin and neurological changes (depression and anxiety) (Estrela et al., 2021).

A set of scientific research points to long-term damage (after 6 weeks or persisting beyond 6 weeks from the onset of coronavirus symptoms) in the sensory system, with emphasis on olfactory and gustatory sequelae, e.g., dysosmia (distorted perception of smells) and dysgeusia (distorted perception of food tastes). There may also be disorders of glucose metabolism (chemical reactions), hyperlipidemia (increased amount of fat in the blood), dysregulation of lipid metabolism (chemical reactions), post-traumatic stress disorder (one of the types of anxiety disorders) and affected lung capacity, damage to the liver (liver) and renal system (kidneys), and possibly in the reproductive system (Sesapr, 2020; Grendene et al., 2021).

Smell dysfunctions have a quantitative classification, in which there is anosmia (no detection of odors), hyposmia (limitation in the detection of odors), hyperosmia (increase in the ability to detect odors) and dysosmia (distorted perception of odors) (Cardoso, 2018). While quantitative dysfunctions in taste can be classified as hypogeusia (partial detection of taste), hypergeusia (increase in gustatory perception capacity), ageusia (total loss of taste) and dysgeusia (distortion in taste) (Barros et al., 2015; Gomes et al., 2020; Machado e Machado, 2020).

The qualitative subclassification of dysosmia (olfactory alteration) is diverse, among the examples one can find parosmia (distorted and unpleasant perception of odors), fantosmia (odor perception in the absence of odoriferous particles) and agnosmia 
(inability to classify different odors) (Cardoso, 2018). Dysgeusia (gustatory alteration) has a qualitative subclassification, also diversified, among examples, parageusia (inadequate perception of taste due to stimulus) and fantogeusia (unpleasant gustatory perception in the absence of stimulus) (Machado and Machado, 2020).

Despite the notes, further studies are needed in relation to the numerous and diverse sequelae due to covid-19 (Grendene et al., 2021), including those affected with reduced symptoms and asymptomatic (Uzun, 2020).

\section{GOAL}

Make a literature review of the last two years on the sequelae of COVID 19 in taste and smell.

\section{METHOD}

A brief literature review was conducted in scientific articles on the sequelae of COVID 19 in taste and smell, between 2020 and 2021, in Portuguese, in the Google Scholar search database. The keywords (or descriptors) "Gustation and COVID19" and "Smell and COVID 19" were used. A total of 1,777 results were found and 10 articles were used to make up this brief review. This allowed the review to be made based on the most up-to-date academic productions (Capes, 2012).

Articles with COVID 19 content and sequelae in taste and smell were used, in Portuguese, within the period limit of the review. Articles that did not meet this content and/or period of time were excluded.

\section{RESULTS AND DISCUSSION}

Table 01 shows the number of articles found by described and the number of articles used within the methodological criteria. 
Table 1 - Number of articles found in the database according to descriptors and articles used

\begin{tabular}{|c|c|c|c|c|}
\hline BASE DE DADOS & DESCRITOR & \begin{tabular}{|c|} 
NUMERO \\
ARTIGOS \\
ENCONTRADOS \\
\end{tabular} & $\begin{array}{c}\text { NUMERO } \\
\text { ARTIGOS } \\
\text { UTILIZADOS } \\
\end{array}$ & \begin{tabular}{|c} 
AUTOR E ANO DOS \\
ARTIGOS \\
UTILIZADOS \\
\end{tabular} \\
\hline \multirow{10}{*}{ Google acadêmico } & \multirow{7}{*}{ Gustação e COVID19 } & \multirow{7}{*}{237} & \multirow{7}{*}{7} & PIMENTEL, 2020 \\
\hline & & & & $\begin{array}{l}\text { GRENDENE et al., } \\
2021\end{array}$ \\
\hline & & & & SANTOS et al., 2020 \\
\hline & & & & COSTA et al., 2020 \\
\hline & & & & SOUZA et al., 2021 \\
\hline & & & & $\begin{array}{c}\text { NOGUEIRA et al., } \\
2021\end{array}$ \\
\hline & & & & NUNES et al., 2020 \\
\hline & \multirow{3}{*}{ Olfato e COVID 19} & \multirow{3}{*}{1540} & \multirow{3}{*}{3} & KOSUGI et al., 2020 \\
\hline & & & & BRITO e SLVA, 2020 \\
\hline & & & & $\begin{array}{c}\text { LOPES e DE ABREU, } \\
2021\end{array}$ \\
\hline
\end{tabular}

RC: 101279

Available in: https://www.nucleodoconhecimento.com.br/health/sequelae-of-covid-19 
Table 02 - shows the methods used in each article selected for this review, the results and conclusions found.

\begin{tabular}{|c|c|c|c|}
\hline $\begin{array}{c}\text { AUTOR E ANO } \\
\text { DOS ARTIGOS } \\
\text { UTILIZADOS }\end{array}$ & $\begin{array}{l}\text { TIPO DE } \\
\text { MÉTODO }\end{array}$ & RESULTADOS & CONCLUSÃO \\
\hline PIMENTEL, 2020 & $\begin{array}{l}\text { Pesquisa } \\
\text { qualitativa } \\
\text { descritiva, } \\
\text { revisão } \\
\text { bibliográfica da } \\
\text { literatura }\end{array}$ & \begin{tabular}{|} 
Estudos dassificaram as disfunções como: \\
anosmia/hiposmia ou ageusia e \\
hipogeusia/disgeusia. Pacientes tiveram os sintomas \\
disfuncionais tanto no olfato quanto na gustação. \\
Não são considerados danos permanentes.
\end{tabular} & $\begin{array}{l}\text { Identificação hiposmia, anosmia, fantosmia e } \\
\text { parosmia, com preval ência entre } 22,7 \% \text { a } 88,8 \% \text {, } \\
\text { associadas ou não hipogeu sia e ag eusia Futuros } \\
\text { estudos epi demi ológicos devem esclarecer como } \\
\text { esses sintomas são causados. }\end{array}$ \\
\hline $\begin{array}{l}\text { SANTOS et al } \\
2020\end{array}$ & $\begin{array}{c}\text { Revisão } \\
\text { Integrativa da } \\
\text { literatura }\end{array}$ & $\begin{array}{c}\text { Preval ência das disfunções sensoriais provocadas } \\
\text { pela COVD-19. Anosmia e disgeusia como } \\
\text { sintomas neurológicos mai s frequentes. Pacientes } \\
\text { que tiveram quadro leve a moderado de COVID-19. } \\
\text { Aumento da idade dos pacientes e quadros mais } \\
\text { severos da doença representam menos al terações. }\end{array}$ & $\begin{array}{l}\text { Sintese de informações de vários paises, } \\
\text { caracterizando as disfunções olfativas e gustativas } \\
\text { como sintomas iniciais. Repercu ssões após alta dos } \\
\text { pacientes. Necessários estudos sobre as } \\
\text { probl emáticas e investigações mais detalhadas. Os } \\
\text { distúrbios poderão ser estudados em um periodo de } \\
\text { tempo maior. }\end{array}$ \\
\hline $\begin{array}{l}\text { NOGUEIRA et al ., } \\
2021\end{array}$ & $\begin{array}{l}\text { Revisão } \\
\text { descritiva }\end{array}$ & $\begin{array}{c}\text { A infecção nos neurônios causa sintomas } \\
\text { neurológicos como anosmia. Não há explicação } \\
\text { exata acerca da ocorrência dos distúrbios olfatórios. } \\
\text { Danos no sistema nervoso central e epitélio nasal, } \\
\text { cau sam a di sosmia e a disgeusia. }\end{array}$ & $\begin{array}{l}\text { Os problemas olfativos e gustativo ocorrem } \\
\text { previamente em diferentes intensidades. Não há } \\
\text { evidências dientificas para o tratamento desses } \\
\text { distúrbios. É importante a realização de estudos } \\
\text { acerca do assunto a fim de que se melhore os } \\
\text { procedimentos no tratamento nos casos, } \\
\text { principalmente, nos casos com sequel as de longo } \\
\text { prazo. }\end{array}$ \\
\hline $\begin{array}{c}\text { COSTA et al., } \\
2020\end{array}$ & $\begin{array}{l}\text { Revisão } \\
\text { Sistemática }\end{array}$ & $\begin{array}{l}\text { Sintomas neurológicos que ocorrem no sistema } \\
\text { nervoso periférico causam as di sfunções olfativa e } \\
\text { gustativa. Pacientes com quadro leve a moderado } \\
\text { apresentaram hipogeusia e hiposmia, não há } \\
\text { registros do inicio, duração e resolução dos } \\
\text { sintomas. Os pacientes com perda de olfato tiveram } \\
\text { menor taxa de internação, compar ados com os } \\
\text { pacientes sem perda de olfato. }\end{array}$ & $\begin{array}{l}\text { Os distúrbios olfativos e/ou gustativos podem } \\
\text { ocorrer em intensidades variáveis, com inicio junto } \\
\text { com os sintomas prévios da infecção. Não há } \\
\text { evidências cientificas acerca do tratamento destes } \\
\text { distúrbios. }\end{array}$ \\
\hline
\end{tabular}

RC: 101279

Available in: https://www.nucleodoconhecimento.com.br/health/sequelae-of-covid-19 


\begin{tabular}{|c|c|c|c|}
\hline $\begin{array}{c}\text { BRITO e SIVA, } \\
2020\end{array}$ & $\begin{array}{l}\text { Revisão da } \\
\text { literatura }\end{array}$ & $\begin{array}{l}\text { Associação de manifestaç̃oses neurológicas e a } \\
\text { COVID-19. Entre elas os distúrbios do olfato e } \\
\text { paladar, como a hiposmia, a anosmia, a disgeusia, } \\
\text { hipogeusia e ageusia. Os mecanismos exatos da } \\
\text { neuroinvasão causada pela COVID-19 ainda são } \\
\text { desconhecidos. }\end{array}$ & $\begin{array}{l}\text { Ocorre uma inci dência maior de danos no sistema } \\
\text { nervoso em quadros agudos da virose. Entretanto a } \\
\text { classificação dos casos agudos e crônicos ainda hoje } \\
\text { não é consenso. São necessários mais estu dos sobre } \\
\text { as sequelas a longo prazo. }\end{array}$ \\
\hline $\begin{array}{c}\text { SOUZA et al., } \\
2021\end{array}$ & Relato de casos & $\begin{array}{l}\text { Ano smia nos pacientes é uma manifestação } \\
\text { sintomal ógica recorrente. Fundamental a descrição } \\
\text { de relatos de casos a fim de esclarecer as } \\
\text { ocorrências de sequelas gustativas olfativas com } \\
\text { objetivo de realializar o manejo da recuperação. }\end{array}$ & $\begin{array}{l}\text { As disfunções devem ser estudadas com maior rigor } \\
\text { e por mai or periodo de tempo. A COVD-19 afeta } \\
\text { as células do epitélio olf ativo, possivelmente } \\
\text { alterando a neurotransmissão. }\end{array}$ \\
\hline $\begin{array}{l}\text { LOPES e DE } \\
\text { ABREU } 2021\end{array}$ & $\begin{array}{c}\text { Metodologia para } \\
\text { tratamento }\end{array}$ & $\begin{array}{l}\text { Possiveis danos neurológicos em nivel celular } \\
\text { decorrentes da COVID-19. Pacientes recuperados } \\
\text { ainda relatam alterações, que podem ser } \\
\text { irreversiveis, nos sentidos olf ativo e gustativo. }\end{array}$ & $\begin{array}{l}\text { As sequelas causadas pela doença podem ser de } \\
\text { cunho neurológicos, em nivel celular ou não. Isso } \\
\text { pode causar transtornos, sindromes e outras } \\
\text { variáveis futuramente. }\end{array}$ \\
\hline $\begin{array}{l}\text { NUNES et al., } \\
2020\end{array}$ & $\begin{array}{l}\text { Revisão } \\
\text { Integrativa }\end{array}$ & $\begin{array}{l}\text { Disfunções olfativas com preval ência entre } 30 \text { a } \\
88 \% \text { dos pacientes com COVID-19 englobados nos } \\
\text { diferentes estudos. Relados por pacientes com } \\
\text { quadros leves e moderados da doença. Os } \\
\text { transtornos como anosmia, hiposmiahipogeusia, e } \\
\text { disgeusia são sintomas frequentes nos pacientes } \\
\text { com COVID-19. }\end{array}$ & $\begin{array}{l}\text { O envolvimento do virus com o sistema nervoso é, } \\
\text { até então, inconclusivo. Entender os sintomas } \\
\text { neuroló gicos, principalmente em quadros mais } \\
\text { graves, auxilia nas intervenções e nos prognósticos } \\
\text { médicos. }\end{array}$ \\
\hline $\begin{array}{c}\text { GRENDENE et } \\
\text { al., } 2021\end{array}$ & $\begin{array}{c}\text { Revisão } \\
\text { bibliográfica }\end{array}$ & $\begin{array}{c}\text { Aponta que existem poucos estudos revisados sobre } \\
\text { a ocorrência ou prevalência das sequelas de longo } \\
\text { prazo da COVID-19. Há algumas evidências de que } \\
\text { disfunções como a disosmia e đisgeusia são } \\
\text { sequelas de longo prazo associadas à COVID-19. A } \\
\text { mai oria não trabalha com periodos de } \\
\text { acompanhamento indicativos de sequelas de longo } \\
\text { prazo. }\end{array}$ & $\begin{array}{l}\text { Não se sabe muito sobre estratégias para tratamento } \\
\text { para este virus. Pesquisas clini cas estão sendo } \\
\text { realizadas para descobrir novos tratamentos. } \\
\text { Prevenção ainda é a melhor forma de lidar. }\end{array}$ \\
\hline $\begin{array}{l}\text { KOSUGI et al., } \\
2020\end{array}$ & $\begin{array}{l}\text { Quali quantitativa } \\
\text { por questionário }\end{array}$ & $\begin{array}{l}\text { Induidos } 253 \text { pacientes, de todas as regi ões } \\
\text { brasileiras, uma maioria apresentou anosmia e } 13 \text {, } \\
2 \% \text { não tiveram recuperação da per da olfativa. } \\
\text { Alteração no paladar não está incluida na pesquisa. }\end{array}$ & $\begin{array}{l}\text { Anosmi a apresenta menor taxa de recuperação e } \\
\text { duração mai or em pacientes por COVD-19 } \\
\text { positivos do que nos negativos. Hiposmia teve } \\
\text { maior taxa de recuperação do que a anosmia. }\end{array}$ \\
\hline
\end{tabular}

Through Pimentel studies (2020) based on 15 publications that described clinical reports in Europe in early 2020, cases of hyposmia, anosmia, fantosmia and parosmia were identified, with prevalence between $22.7 \%$ and $88.8 \%$, associated or not hypogeusia and ageusia.

The amplitude of sensory symptom rates/sequelae is due to the difference between studies, as well as the instruments used by these varied scientific researches, and even genetic differences in the population (Pimentel, 2020). Population differences show that the occurrence rates of olfactory-taste abnormalities are higher, for example, in populations in Europe, North Africa, South Asia and Western Asia, compared to the lowest rates presented by patients in East Asia (Santos et al., 2020). Females and younger people seem to be the most affected by olfactory and 
gustatory disorders (Costa et al., 2020; Nascimento, 2020). This difference probably occurs because there is a difference in physiological defense reaction between age groups and genera of the human species (Cardoso et al., 2020).

The study by Santos et al. (2020) highlights that olfactory and gustatory dysfunctions as initial symptoms, and that it has greater repercussion after discharge of patients.

The hospital treatment of patients ends before the appearance of sequelae, probably because there is a historical deficiency of vacancies and health professionals in Brazil. The increase in the hospital flow of patients during the pandemic seems to have aggravated the situation, preventing specific and thorough follow-up, as care was already precarious (Santo et al., 2021).

In the integrative review by Nogueira et al. (2021) it was identified that olfactory and gustatory problems occur previously at different intensities. There is no scientific evidence for the treatment of these disorders.

Costa et al. (2020) identified that olfactory and/or gustatory disorders may occur at varying intensities, with onset along with previous symptoms of infection. There is no scientific evidence on the treatment of these disorders.

The human immune system varies according to some physical and physiological characteristics (Cardoso et al., 2020). The intensity of symptoms may occur due to these variations. In women the hormones produced in menstrual cycles, those present in the contraceptive pill and in the treatment of hormone replacement (to combat menopausal symptoms) affect the defense system, making it different from that of men (Rogero et al., 2021).

Age is also a factor for the difference in onset of symptoms. In contrapoint to Costa et al. (2020) and Nascimento (2020), an older age seems to be more susceptible to the symptoms caused by the virus. An older intestine typically has a lower absorption of nutrients and defense cell production. The difference in concept between the authors may be related to the specific type of symptom (Rogero et al., 2021). 
Stress also affects immune defense function. The nervous system influences the production and release of hormones that can mediate this function (Rogero et al., 2021). Younger people, because of their shorter experience, may be more affected by stress.

As for the treatments studied in the action against olfactory and gustatory disorders, the literature presents the use of corticosteroids (anti-inflammatory action) of the oral and oral, olfactory training, vitamin A and sodium citrate. There are other therapeutic alternatives, but those presented above are more conducive to effectiveness. Nevertheless, there is insufficient or sufficient evidence about the efficacy of these treatments (Cardoso et al., 2020; Costa et al., 2020; Felipe et al., 2021; Neta et al., 2021).

Through a literature review (Brito e Silva, 2020), they believe that there is a higher incidence of damage to the nervous system in acute cases of the virus. However, the classification of acute and chronic cases is still not consensus.

Souza et al. (2021) concluded that dysfunctions should be studied more rigorously and for a longer period of time. COVID-19 affects olfactory epithelium cells, possibly altering neurotransmission.

The study by Lopes and De Abreu (2021) reports that the sequelae caused by the disease may be neurological in nature, at the cellular level or not. This can cause disorders, syndromes and other variables in the future.

Olfactory and gustatory dysfunctions, in general, occur in an associated way, since the olfactory and gustatory senses (chemical senses, perceive the substances in the nasal and oral cavity) work together and the taste sensations depend exclusively on smell. Sensory sensations happen due to the interaction of molecules with the receptors of smell and taste. Taste receptors (found in regions of the tongue, palate, pharynx, epiglottis and esophagus) are responsible for sending gustatory information through nerve impulses (communication between cells, neurons) to the central nervous system. In smell, olfactory information is also transmitted to the central 
nervous system through neurons that communicate by electrical currents (synapses) (Neto et al., 2011; Oliveira, 2014).

The COVID19 virus causes injury to olfactory neural cells, because in the nasal epithelium there are a high amount of enzymes that facilitate the diffusion and replication of it. In response to infection the immune system "activates" the defense system by cytosines (proteins), the so-called cytopathic effect, which can compromise the neurotransmission process, causing olfactory loss. This also occurs with taste, where the inflammatory process (cytopathic effect) decreases the life of the receptor cells of the taste buds (Cardoso et al., 2020; Felipe et al., 2021)

Scientific analyses demonstrate the probability of the virus reaching the nasal epithelium, not neurons directly. The cells of the nasal epithelium retain the so-called ionic balance of mucus, on which neurons depend to make the synapses up to the central nervous system. When this balance is impaired the smell ceases to function as it should, damage to olfactory neurons may occur. Still, there is no proof whether anosmia results directly from the virus or if it is the result of an immunological response (Nishioka, 2020).

In the gustatory sense, gustatory receptor cells are not affected by the virus, but rather the support cells, which may explain the cases of loss of taste. The olfactory epithelium has the ability to regenerate, that is, anosmia is considered reversible, however, patients with slow recovery from this dysfunction may present another disorder, parosmia, in which the flavors (sweet, bitter, salty, sour) are recovered, but certain odors and aromas become unpleasant (Nishioka, 2020).

Nunes et al. (2020), in their review, found that the involvement of the virus with the nervous system is, until then, inconclusive. Understanding neurological symptoms, especially in more severe conditions, helps in interventions and medical prognoses.

The involvement of the virus with the nervous system seems to be inconclusive. Currently, there are two main theories that explain the neurological impacts of COVID-19 on humans, the first corresponds to the action of the virus in immune 
dysregulation, such as overproduction of cytosines, and thus causing neurological symptoms. Indicating the possibility of the virus spreading through blood and neural pathways to the nervous system. The second suggests that infection in the central nervous system occurs through peripheral neurons infected by the virus (Felipe et al., 2021).

Brito e Silva (2020), Pimentel (2020), Santos et al. (2020) and Nogueira et al. (2021) agree on the little knowledge that exists today and propose the continuity of studies on the symptoms of COVID 19. This is important because through scientific studies it will be possible to define the causes of the mechanisms that cause olfactory-taste changes and provide a basis for the research of appropriate treatments for those affected (Nishioka, 2020; Santos et al., 2020; Felipe et al., 2021; Lima et al., 2021; Oliveira et al., 2021).

In the literature review by Grendene et al. (2021) the conclusion indicates that not much is known about strategies for treatment for this virus. That's why clinical research is being conducted to discover new treatments. Prevention today is still the best way to deal with infection.

Prevention measures against the virus include: hand hygiene often, done by washing with soap and water (breaking the virus's lipid wall and kills it) and/or using $70 \%$ ethyl alcohol, avoiding the hands with eyes, nose and mouth, practicing respiratory labeling (care when coughing or sneezing), wearing face masks (physical barrier against hanging droplets), social distancing of at least one meter, disinfection of objects and surfaces, symptomatic keep in isolation, aesthetise indoors, avoid handshakes and hugs and avoid social contact. All are indicated according to scientific basis (Stephens et al., 2009; Baptista and Fernandes, 2020; Garcia, 2020; Soares et al., 2021; Spdm, 2021).

In relation to social isolation, studies indicate its efficacy and aid in reducing infection rates, however, it should be done in association with other virus containment meditations (Who, 2021). There are also proofs about the aeration of closed places when exposed to sunlight and keep them ventilated, because such environments 
contain the water vapor droplets from coughing, sneezing and the very act of talking about individuals,(Opas, 2021). The use of masks is scientifically proven, it is known that this PPE (personal protective equipment) is a physical barrier, a wall, against the COVID-19 virus (Salles et al, 2021). In addition, it is emphasized that even after vaccination people should not stop using/applying the prevention mechanisms against the virus (Brasil, 2021a).

Kosugi et al. (2020) conducted an online survey and concluded that anosmia has a lower recovery rate and longer duration in covid-19 positive patients than in negative patients. Hyposmia had a higher rate of recovery than anosmia.

In hyposmia, because it is a partial loss, it is possible to "train" the smell. Odors and essential oils are used twice a day for six months for this purpose. Already more severe loss, anosmia, if there is no instant recovery the treatment is drug and prolonged (Pereira et al., 2020). This probably explains the difference in recovery rates of both sequels

\section{CONCLUSIONS}

The sequelae of COVID-19 are diverse disorders that compromise the sensory senses (smell and taste) in different degrees, affecting the well-being and daily life of thousands of people.

Women and young people are the most affected by these dysfunctions. It is not known exactly how the virus causes neurological symptoms in patients, and the exact means by which dysfunctions occur. Also, there are no specific and scientifically proven treatments to the various dysfunctions, but the most indicated is the practice of olfactory training.

Studies related to dysfunctions are limited, mainly, in Brazil and when they are analyzed as sequelae, that is, studied after a certain period after recovery of COVID19 patients. The continuity of scientific research is indispensable, because only this process will be able to elucidate the doubts that still exist and generate appropriate 
treatments for people who developed COVID-19 and were left with some of the various types of sequelae, including sensory ones.

\section{REFERENCES}

BAPTISTA, A. B.; FERNANDES, L. V. COVID-19, análise das estratégias de prevenção, cuidados e complicações sintomáticas. Revista Desafios, v. 7, p. 1-10, 2020.

BARROS, Ó. D. et al. Disgeusia: a propósito de um caso clínico. Revista Portuguesa De Medicina Geral E Familiar, v. 31, n. 4, p. 272-276, 2015.

BRANDÃO, R. E. L. Vírus e Retrovírus: Contributo para a Evolução das Espécies. 2015. 61p. (Mestrado). Faculdade de Ciências da Saúde, Universidade Fernando Pessoa, Porto PT.

BRASIL. Coronavírus - Como é transmitido? , Brasília DF, 2021. Disponível em: < https://www.gov.br/saude/pt-br/coronavirus/como-e-transmitido >. Acesso em: 06 set 2021.

- Doenças ocasionadas por vírus respiratórios emergentes, incluindo o COVID-19. Brasília DF, 2021a. Disponível em: < https://www.unasus.gov.br/cursos/curso/46164 >. Acesso em: 06 set 2021.

BRITO, W. G. F.; SILVA, J. P. D. O. Impactos neuropatológicos do COVID-19. Brazilian Journal of Health Review, v. 3, n. 3, p. 4227-4235, 2020.

CAPES. Treinamento no uso do Portal de Periódicos. Brasilia DF, 2012. Disponível em: < https://www.fca.unesp.br/Home/Biblioteca/portal-capes.pdf >. Acesso em: 06 set 2021.

CARDOSO, A. R. Olfato como Marcador Biológico. 2018. 21p. (Mestrado). Universidade de Lisboa, Lisboa PT. 
CARDOSO, M. D. C. et al. Anosmia e disgeusia no paciente com coronavírus: revisão narrativa. REAS/EJCH, v. 46, p. 1-8, 2020.

COSTA, K. V. T. D. et al. Desordens olfativas e gustativas na COVID-19: uma revisão sistemática. Braz J Otorhinolaryngol., v. 86, n. 6, p. 781-792, 2020.

ESTRELA, M. C. A. et al. Covid-19: sequelas fisiopatológicas e psicológicas nos pacientes e na equipe profissional multidisciplinar. Brazilian Journal of Development, v. 7, n. 6, p. 59138-59152, 2021.

FELIPE, L. P. et al. Compreensão das manifestações neurológicas induzidas por infecções pelo novo coronavírus: uma revisão integrativa. REAID, v. 95, n. 36, p. e21137, 2021.

FILHO, N. D. A. O que é saúde? Rio de Janeiro RJ: Editora Fiocruz, 2011. 160p.

GARCIA, L. P. Uso de máscara facial para limitar a transmissão da COVID-19. Epidemiol. Serv. Saude, v. 29, n. 2, p. 1-4, 2020.

GOMES, D. R. D. P. et al. Avaliação do paladar de idosos e sua relação com estado nutricional e hábitos alimentares. Pan American Journal of Aging Research, v. 8, n. 1, p. 1-8, 2020.

GRENDENE, C. S.; GULO, R. B.; BETIOL, R. S. M. Coronavírus (covid-19): história, conhecimento atual e sequelas de longo prazo. Revista Corpus Hippocraticum, v. 1, n. 1, p. 1-14, 2021.

ISER, B. P. M. et al. Definição de caso suspeito da COVID-19: uma revisão narrativa dos sinais e sintomas mais frequentes entre os casos confirmados. Epidemiol. Serv. Saude, Brasília, v. 29, n. 3, p. 1-11, 2020.

KOSUGI, E. M. et al. Recuperação incompleta e tardia da perda súbita do olfato na COVID-19. Braz. j. otorhinolaryngol., v. 86, n. 4, p. 490-496, 2020. 
LIMA, J. H. C. et al. Covid-19 e os danos ao aparelho olfatório causando anosmia. Revista Científica Multidisciplinar, v. 2, n. 8, p. e28665, 2021.

LOPES, D. O.; DE ABREU, F. Eletroterapia IVL no tratamento de Covid-19 e sequelas no sistema nervoso central. Brazilian Journal of Development, v. 7, n. 4, p. $42332-423402021$.

MACHADO, A. L. M.; MACHADO, M. C. M. Disgeusia: Revisão de Literatura. 2020. 56p. (Graduação). Universidade de Uberaba, Uberaba MG.

NASCIMENTO, M. A. Alteração das funções sensoriais de olfato e paladar e seus correlatos clínicos e funcionais em indivíduos com Covid-19. 2020. 71p. (Mestrado). Universidade Federal do Rio Grande do Norte, Santa Cruz.

NETA, F. I. et al. Pathophysiology and possible treatments for olfactory-gustatory disorders inpatients affected by COVID-19. Current Research in Pharmacology and Drug Discovery, v. 2, p. 1-11, 2021.

NETO, F. X. P. et al. Anormalidades sensoriais: Olfato e paladar. Arquivos Int. Otorrinolaringol., v. 15, n. 3, p. 350-358, 2011.

NISHIOKA, S. D. A. A perda de olfato na COVID-19 já tem explicação - pelos menos em parte. 2020. Disponível em: < https://www.unasus.gov.br/especial/covid19/markdown/335 >. Acesso em: 30 out 2021.

NOGUEIRA, J. F. et al. Distúrbios olfatórios decorrentes de infecção por SARSCoV-2: fisiopatologia, fatores de risco e possíveis intervenções. Research, Society and Development, v. 10, n. 11, p. 1-7, 2021.

NUNES, L. T. D. et al. Principais Manifestações Neurológicas decorrentes do COVID-19: uma revisão integrativa. Revista Saúde Coletiva, v. 10, n. 59, p. 42484254, 2020. 
OLIVEIRA, A. A. D. et al. Análise dos principais fatores de risco preexistentes em pacientes diagnosticados com a COVID-19 no Amapá, Amazônia, Brasil. Revista Científica Multidisciplinar Núcleo do Conhecimento, v. 17, p. 56-72, 2021. Disponível em: < https://www.nucleodoconhecimento.com.br/saude/riscopreexistentes $>$.

OLIVEIRA, F. V. Aromas: contextualizando o ensino de Química através do olfato e paladar. 2014. 137 p. (Mestrado). Universidade de Santa Maria, Santa Maria RS.

OMS. Série de documentos de informação sintéticos do escritório regional da oms para a áfrica sobre a COVID-19. Africa, p. 1-6, 2021. Disponível em: < https://apps.who.int/iris/bitstream/handle/10665/338819/WHO-AF-ARD-DAK-102021-por. pdf? sequence=1\&isAllowed=y >. Acesso em: 30 out 2021.

OPAS. Roteiro para melhorar e garantir a boa ventilação de ambientes fechados no contexto da doença causada pelo novo coronavirus, COVID-19. Washington D.C., 2021. Disponível em: < https://iris.paho.org/handle/10665.2/53938 >. Acesso em: 01 out 2021.

PEREIRA, A. C. C. M. et al. Revisão bibliográfica: Anosmia no COVID-19. Revista Cien, v. 15, n. 2, p. 96-, 2020.

PIMENTEL, B. N. As disfunções olfativas e gustativas como apresentação clínica da COVID-19. Research, Society and Development, v. 9, n. 8, p. e64985072, 2020.

ROGERO, M.; NATACCI, L.; AMANCIO, O. Nutrição \& Imunidade. São Paulo SP: SBAN, 2021. 27p.

SANTO, D. M. N. D. E. et al. Desafios do enfermeiro do Centro Cirúrgico frente à pandemia da COVID-19 e transição de uma sala cirúrgica em unidade de terapia semi-intensiva. REAS, v. 13, n. 6, p. 1-6, 2021. 
SANTOS, I. H. A. et al. Disfunções olfativas e gustativas na COVID-19. Research, Society and Development, v. 9, n. 12, p. e42591211363, 2020.

SESAPR. Reabilitação do paciente pós tratamento de infecção por SARS- CoV-2. Curitiba PR, 2020. Disponível em: < https://www.saude.pr.gov.br/sites/default/arquivos_restritos/files/documento/202012/Nota\%20orientativa\%20n\%C2\%BA\%2053\%20reabilita\%C3\%A7\%C3\%A3o.pdf >. Acesso em: 09 set 2021.

SILVA, A. W. C. et al. Caracterização clínica e epidemiologia de 1560 casos de COVID-19 em Macapá/AP, extremo norte do Brasil. Research, Society and Development, $\quad$ v. $9, \quad$ n. 8 , p. 1-21, 2020a. Disponível em: < https://rsdjournal.org/index.php/rsd/article/view/5499/4641 >.

SILVA, A. W. C. et al. Perfil epidemiológico e determinante social do COVID-19 em Macapá, Amapá, Amazônia, Brasil. Revista Científica Multidisciplinar Núcleo do Conhecimento, v. 4, n. 4, p. 05-27, 2020. Disponível em: < https://www.nucleodoconhecimento.com.br/saude/covid-19-em-macapa >.

SOARES, K. H. D. et al. Medidas de prevenção e controle da covid-19: revisão integrativa. Revista Eletrônica Acervo Saúde, v. 13, n. 3, p. 1-11, 2021. Disponível em: < https://doi.org/10.25248/reas.e6071.2021 >.

SOUZA, F. D. S. et al. "Anarquia do paladar" e anosmia pós-COVID-19: Seriam danos permanentes? Relato de casos. Revista de Ciências Biológicas e da Saúde, v. 4, n. 1, p. 1-6, 2021.

SOUZA, K. O. et al. Covid-19 e o cenário atual da Cidade de Castanhal PA, Brasil. Research, Society And Development, v. 9, n. 8, p. 1-17, 2020. Disponível em: < https://rsdjournal.org/index.php/rsd/article/view/5717/4998 >.

SPDM. HMB explica por que a higienização das mãos auxilia na prevenção da Covid-19. São Paulo SP, 2021. Disponível em: < https://www.spdm.org.br/saude/noticias/item/3390-hmb-explica-por-que-a- 
higienizacao-das-maos-auxilia-na-prevencao-da-covid-19 >. Acesso em: 04 out 2021.

STEPHENS, P. R. S. et al. Virologia. In: MOLINARO, E. M.;CAPUTO, L. F. G., et al (Ed.). Conceitos e métodos para a formação de profissionais em laboratórios de saúde. Rio de Janeiro RJ: EPSJV, v.4, 2009. p.125 - 220.

THEY, N. H. Você sabe o que é um vírus? Microbiologando Porto Alegre RS, 2020. Disponível em: < https://www.ufrgs.br/microbiologando/voce-sabe-o-que-eum-virus/ >. Acesso em: 06 set 2021.

UZUN, A. C. D. S. B. Sequelas da Covid-19 vão além da fadiga, ressalta especialista. Campo Grande MS, 2020. Disponível em: < http://www.ms.gov.br/sequelas-da-covid-19-vao-alem-da-fadiga-ressalta-especialista/ >. Acesso em: 06 set 2021.

VANA, L. P. M.; SCHIOZER, W. Sequelas de queimaduras: nova classificação. Rev Bras Queimaduras, v. 12, n. 3, p. 192, 2013.

Submitted: November, 2021.

Approved: November, 2021. 